\title{
EVALUATING THE EFFECTIVENESS OF BRAND POSITIONING FROM A CONSUMER PERSPECTIVE
}

Assistant professor, dr. Tina Vukasović

International School for Social and Business Studies, Mariborska cesta 7, SI - 3000 Celje, Slovenia; DOBA Faculty, Prešernova 1, SI - 2000 MariborSlovenia; University of Primorska, Faculty of Mathematics, Natural Sciences and Information Technologies, Glagoljaška 8, SI-6000 Koper, Slovenia

E-mail: tina.vukasovic@mfdps.si

Martina Barkovič, mag.

Ministry of the interior, Police, Police Station Brežice, Prešernova cesta 19/a, SI - 8250 Brežice, Slovenia E-mail: plevnikti@gmail.com

\section{ABSTRACT}

Companies must, in the present modern times of great changes and requirements, adapt continuously to consumer preferences, in order to remain competitive. Companies are striving to change consumer perception with brand positioning, they would like to draw their attention, ofer them everything they whish for and simply beacuse they are trying to become the best in their field. However, all of this is not possible without employees, their knowledge, skills and motivation to carry out their work which can be obtained in various ways. This paper introduces the results of research in which we analyse the effectiveness of positioning the brand in the eyes of consumers and managers in the studied company and the importance of knowledge management in this process. Our results confirm the good brand positioning, which the respondents confirmed, slightly lower estimate of the assigned point-brand was received from guests that came from abroad. For the company to effectively position their brand abroad, it is necessary to know the employees, which are a key factor in the situation of the company, its visibility and positioning. It is important that the employees use knowledge management system and than capture, discover, share and use received knowledge.

\section{Indexing terms/Keywords}

Marketing; Brand management; Brand, Brand positioning; Consumer perception; Knowledge; Knowledge management.

\section{Academic Discipline And Sub-Disciplines}

Marketing, Brand management.

\section{SUBJECT CLASSIFICATION}

Marketing.

\section{TYPE (METHOD/APPROACH)}

Survey/Interview.

\section{Council for Innovative Research}

Peer Review Research Publishing System

Journal: Journal of Social Sciences Research

Vol. 6 , No. 1

Jssreditor.cir@gmail.com

www.jssronline.com 


\section{INTRODUCTION}

Nowdays, a brand plays a key role in the eyes of the consumer, because it has become their status symbol, it makes a purchase easier, represents quality, trust and consistency, as well as the emotional benefits at the end (Vukasović, 2012, 270). Going though literature, we come across different interpretations of the brand, but when we sum up the essence, we come to the conclussion that they express the same thing. The most traditional interpretation is the interpretation of the American Marketing Association (American Marketing Association - AMA), which defines the brand as a "name, term, sign, symbol, design or combination of them, intended to identify products or services of one or group of sellers and to differentiate their products or services from the competition" (AMA in Konečnik, 2006, 266). Modern definitions of the brand are appearing increasingly, which is described by Konečnik Ruzzier $(2011,157,158)$ as a complex entity that requires a comprehensive treatment and view of it. We can highlight its comprehensive treatment of both internally, where the brand is equated with the company as an external point of view, where there is a perception of the brand by potential consumers. Particular emphasis is placed on the interconnection between the two aspects. "Positioning starts with a product - it can be a piece of goods, services, company, institution, or even a person. In the process of brand positioning companies need to focus on to final consumers. There is no need to change the product or offer, they must try and change the thinking of the final consumer, which means that they must work on the basis of their products and services to change the consumer's perspective (Barkovič, 2014).

Spa tourism represents one of the most stable industries in Slovenia. In addition, health tourism is also one of the most promising industries, which is why the brand is very important in consumer decision making and what in fact makes one company different from competition. The problem is, that in Slovenia the offer of Health tourism is huge and therefor hpe the company positions the brand is so much more important. Every company wants the best market position and competitive tender. As Brezovec and Nemec Rudež state $(2009,120)$, the ideal position, that tourism business want to have in the eyes of the tourists is - to be "the" biggest, best, closest, cheapest, ... tourist companies seek to highlight its advantage - competitive advantage. One of these tourism businesses also studied the company, which in 2000 decided to get a new name and brand image, and since then every year they prepare something new, better, superior. This paper presents the results of research in which we analyze the effectiveness of positioning the brand in the eyes of consumers and managers in the studied company and the importance of knowledge management in this process. As Vukasovic writes $(2009,270)$, brand make choices easier for consumers, because they know exactly which benefits will be gained by selecting the established brands, and beside gaining functional benefits, they will also gain emotional benefit. For a strong brand is important for both internal group (identity) as well as external groups. Konečnik Ruzzier (2011, 159) describes, that behind a successful brand a clear managerial and marketing strategies are being created, which are carefully planned and carried out by its internal stakeholders (managers, trustees, employees). Employees are those who assert the brand in the market. We are interested to know how the company takes care of upgrading the old foundations and how they are facing increasing innovations and the requirements of modern times.

"Strong and successful brands are not a matter of coincidence and luck, they are a reflection of good and systematic work over a longer period of time« (Konečnik Ruzzier, 2011, 155 For a strong and successful brand knowledge is essential, both explicit and tacit knowledge, the employees have in the company and it is important that this knowledge is transmitted, reveals covers and usedWhen all of this is connected, we can talk about knowledge management. As Wiig writes (in Gomezelj Omerzel, Biloslavo and Trnavčevič, 2010, 13), business knowledge management is tracking business strategy, management of intellectual capital, emphasizing personal responsibility, highlighting the organization as a learning organization and systematic concern for the transfer of knowledge to those places where knowledge is most effective when working in accordance with the objectives set. For a brand to be successfuly positioned, knowledge is very important, as Richards, Foster and Morgan say (in Kozjan and Gomezelj Omerzel, 2012, 13), implicit and explicit knowledge both identify in the process of knowledge management about a brand, which results in an increase in brand value. From this it can be assumed that it is important that employees have the right skills to help them both in positioning the brand as well as in other areas of the company. We also cannot ignore the fact, that all together, the relationship with knowledge management is in fact very important.

\section{THE ROLE AND IMPORTANCE OF KNOWLEDGE MANAGEMENT IN THE PROCESS OF BRAND POSITIONING}

When we talk about knowledge management, we are talking about the top management on one hand and the management of knowledge of every individual and across the organization on the other hand. One with the other is closely intertwined (Možina, 2006, 129). The enterprise knowledge management usually means the systematic management and thus rational use of knowledge. It is a great technical and organizational challenge requires the development of appropriate human relations, as well as its effective integration with a wide range of new technological opportunities (Pučko, 1998, 54).

Knowledge management is very important and a key factor for successful and efficient businesses because of globalization, because of the need for a quick response of companies, due to changes in the market. Knowledge management is required due to customer orientation through the provision of services, mobility of workers and the adoption of modern knowledge in a new way because of the rapid development of technology and competitive matches between firms. For all of the above the effective use of knowledge is needed (Možina, 2006, 129). Gomezelj Omerzel $(2008,39)$ states that the business world has fully adopted the belief, that knowledge has become one of the most strategic resources of the organization, especially a major factor in the competitiveness and performance of the company. 
Knowledge of the company, therefore, reflects the company's ability to behave differently from competitors, thereby gaining a competitive advantage (Leonard-Barton v Gomezelj Omerzel, 2008, 63).

Knowledge management helps to improve the learning of the employees and provides exposure to the latest knowledge in the relevant fields, help them in the process of externalization and internalisation (Dermol, 2011, 52). By positioning the brand companies want to change the perception of consumers, lure them on their side, offer them everything they want, and easily become the best in the field. However, all this is not possible without employees and their knowledge, skills and motivation to carry out their work, which can be obtained in variety of ways. Knowledge management skills will help the company that employees will gain even more knowledge and help the company to reach the goals that they have set for themselves. We must be aware of the importance of management skills needed in positioning the brand, as companies and employees strive to continually study the competition, the requirements of consumers and are trying to be "the" best, prettiest, kindest in the eyes of consumers as well as in their own eyes .

\section{RESEARCH DESIGN}

When we read the history of the studied company, which is named after the medieval monastery, situated in the immediate vicinity, we can not imagine that what we have today is an extremely successful company that has worked on the development of health tourism and with its comprehensive tourist offer in the field of health, wellness, accommodation facilities, swimming pool complexes, catering services and attractive location to attract visitors from all parts of the world (Terme Olimia, b. I.). The company has developed extremely quickly, after changing the company's name and with that the brand. The company has added a slogan "renewed life" to the brand, because with programs for individual wishes and needs, a comprehensive wellness facilities, with the latest and greatest saunas, excellent services and beauty treatments, challenges for the adrenaline water adventure and recreation facilities consist of a mosaic of it. Studied company changed its name in 2000, brand and then developed rapidly. Company strived to become the best company in the field of health tourism both at home and abroad. In this study, we studied the responses of consumers - tourists on offer in the studied company and try to determine, whether the company is doing enough to be competitive, using knowledge management and its relationship with the brand positioning.

The aim of the research is to examine the brand positioning both on the part of consumers to identify any defects in the brand positioning and to identify the importance and role of knowledge management in the process of brand positioning of the studied company. Based on the results of the survey at the end of the article we present proposals under consideration the company to improve the brand positioning both at home and abroad.

\section{Methodology, data collection and sample}

We have used quantitative methodology in this study to examine the problem. Quantitative research was conducted through a questionnaire. We choose the method of direct survey of the respondents that were present at various locations of the studied company but at different times. It was intended for the consumers - visitors, and therefore it was also translated into English and German. The questionnaire was pilot tested on three randomly selected guests at first because we wanted to obtain information about the progress of the survey, contact with the respondents and the difficulty of individual questions (Flere, 2000, 126). Men and women who have tested the questionnaire had no major comments, they had presented only a few minor design adjustments. The questionnaire consisted of two parts where in the first part consists of demographic data. Data from the demographic work was processed using Microsoft Excel and R-Commander. The second part is consisted of 12 questions, of which 10 are closed-ended and 2 open-ended questions. In two closedended questions were used Likert scale, where it is mainly for socio-psychological approaches in nature, where the sociological problems and approaches to reduce psychological (Flere, 2000, 221). It consists of a series of arguments that express a position on the specific facility where the respondent state to what extent it agrees or disagrees (Rode, bl), ie, the "degree of consenting or not consenting to the set arguments on the five-point scale" (Cencič, 2009, 73). The questions that we have obtained with closed-type questions, were processed statistically and graphically, using Microsoft Excel and R-Commander. The information, which we have obtained with open-ended questions, the technique of encoding was used and classified into groups (Mesec, 1998, 106-113).

The questionnaire results consisted of only adult tourists and visitors of the studied company. Estimated sample of the survey was 200 respondents, and many have replied to the questionnaire, of which 6 respondents replied to the questionnaire incomplete, but that did not present a problem in this study, reason why they were not eliminated. In the interview there were tourists from 12 countries. Most of the guests come from Slovenia 112 (56\%), there were also tourists from Netherlands $19(10 \%)$, Germany $15(7.5 \%)$, Croatia $13(6.5 \%)$, Austria $10(5 \%)$, Belgium $10(5 \%)$, Italy 6 (3\%), Serbia 5 (2.5\%), Russia 4 (2\%), Denmark $3(2 \%)$, Ukraine $2(1 \%)$ and Switzerland, $1(0.5 \%)$.

There were respondents involved in this survey, of which $82(41.5 \%)$ were men (M) and $116(58.5 \%)$ women (W). Two respondents did not submitt their gender. Respondents participated in different age groups. In the age group of 18-30 years, there was $70(35 \%)$ respondents, of whom $28(14 \%)$ were men and $42(21 \%)$ were women, which was also the largest representation, as shown in table 1.

Table 1: Age groups of respondents by gender

\begin{tabular}{|c|c|c|c|c|c|}
\hline \multirow{3}{*}{ Gender } & \multicolumn{5}{|c|}{ Age group } \\
\cline { 2 - 6 } & $18-30$ & $31-40$ & $41-50$ & $51-60$ & nad 61 \\
\hline
\end{tabular}




\begin{tabular}{|c|c|c|c|c|c|}
\hline male & 28 & 18 & 15 & 13 & 8 \\
\hline female & 42 & 33 & 13 & 18 & 10 \\
\hline Total & $\mathbf{7 0}$ & $\mathbf{5 1}$ & $\mathbf{2 8}$ & $\mathbf{3 1}$ & \\
\hline
\end{tabular}

\section{The research hypothesis}

Based on a review of a relevant literature and researches that were carried out up until this day, there are hypotheses listed below, which are verifiable in practice and are empirically tested using statistical methods:

H1: Brand Terme Olimia has a well-positioned brand both at home and abroad.

$\mathrm{H} 2$ : Modern outlook of the company and rich Wellness offer has attracted increasing interest with young couples.

$\mathrm{H} 3$ : An interesting history and atractive offer of surroundings has contributed a great deal to the brand positioning.

$\mathrm{H} 4$ : The company gives strong emphasis on education, training and motivating of its employees.

In the following paper we present the major results of a survey with which we verified our hypothesis.

\section{RESULTS AND DISCUSSION}

Studied company, Terme Olimia, has chosen an interesting slogan "Revitalize your life," by which they want to tell you, tell us, that consumers can rejuvenate themselves in Terme Olimia. The company offering consumers everything they need for them to feel good and relaxed. The company strives to be the best and the most beautiful in all areas, so far we must say that very successfully, currently it is ranked among the top providers in their field, which means that they are doing almost everything they can for the brand positioning. Less than half of all respondents $93(46.5 \%)$ agreed that the company is well recognized and has good brand positioning in Slovenia, 48 (24\%) of the respondents agreed fully, 52 $(26 \%)$ of respondents agreed partly. Respondents rated the visibility and brand positioning, with an average value of 3.93 . The results are shown in Table 2. Arguments were evaluated on a five-point scale, where 1 meant "strongly disagree" and 5 "totally agree" with the statement in the research. The lowest level of agreement respondents assigned to the claim "Terme Olimia has good visibility and good positioning abroad as well.", with an average of 3.53. The highest level of agreement, however, respondents assigned to the claim "Employees in Terme Olimia are friendly, motivated and well trained to do their jobs.", Which is an average of 4.49 and what makes the lowest SD (0.69), which means that the respondents answered very uniform. In two assertions, one respondent has not delivered its assessment.

\section{Table 2: The average value and standard deviation of the argument}

\begin{tabular}{|l|l|l|l|}
\hline To what extent do you agree with these statements? & PV & SD & $\mathbf{n}$ \\
\hline Terme Olimia have good visibility and good positioning in Slovenia & 3.93 & 0.79 & 200 \\
\hline Terme Olimia have good visibility and good positioning abroad as well. & 3.53 & 0.90 & 199 \\
\hline Modern architectural appearance of buildings attracts large numbers of visitors. & 3.99 & 0.81 & 200 \\
\hline Modernly decorated Wellness Orhidelia attracts mainly younger couples. & 4.00 & 0.96 & 199 \\
\hline $\begin{array}{l}\text { Wellness Orhidelia has a great influence on the decision of tourists whether they } \\
\text { visit Terme Olimia or not. }\end{array}$ & 4.02 & 0.84 & 200 \\
\hline $\begin{array}{l}\text { Tidiness of the Terme Olimia and the surrounding area contributes to the brand } \\
\text { positioning. }\end{array}$ & 4.23 & 0.74 & 200 \\
\hline $\begin{array}{l}\text { An interesting history of the surrounding area attracts tourists in Terme Olimia. } \\
\text { Employees in Terme Olimia are friendly, motivated and trained to perform their } \\
\text { work. }\end{array}$ & 3.49 & 0.69 & 200 \\
\hline $\begin{array}{l}\text { Unspoiled nature and a wide offer of sports activities in the area are of great } \\
\text { importance in deciding about what holiday destination to choose. }\end{array}$ & 4.41 & 0.72 & 200 \\
\hline
\end{tabular}

Note: PV - average value, SD - standard deviation, $\mathrm{n}$ - the number of respondents

About a third $70(35 \%)$ of respondents also agreed, that the company is well positioned abroad, $30(15 \%)$ were in full agreement, $77(38.5 \%)$ partly agreed, which brought the average value to 3.53 . More than half of the respondents 101 $(50.5 \%)$ believe that Terme Olimia is very well recognized in relation to other resorts in Slovenia, 57 (28.5\%) had estimated that the visibility is excellent. Based on the results we can confirm $\mathrm{H} 1$ : "studied company has a well-positioned brand, both at home and abroad".

When we think of the well-positioned brand Term Olimia, we immediately think about modern architectural look and a rich spa offer. And we were not mistaken, because the vast majority of respondents liked that, we also exposed young couples, where we included respondents between 18 and 30 years of age, who came to Terme Olimia with their partners. 
All respondents who had come with their partners, were all together 50 (25\%), of which there were $20(10 \%)$ who have occupied the age category 18-30 years. It was $70(35 \%)$ of all respondents in the category of $18-30$ years, of which 20 $(10 \%)$ came with a partner. $91(45.5 \%)$ respondents were fully satisfied with spa offer, of which $8(4 \%)$ of respondents fell into the category of young couples, out of $80(40 \%)$ of respondents were $9(4.5 \%)$ in the category of young people couples that were satisfied with spa offer. $95(47.5 \%)$ respondents liked the modern architectural look very much, of which 7 $(3.5 \%)$ out of the group of young couples, 79 (39.5\%) respondents liked it, of which $9(4.5 \%)$ out of the group of young couples. With regard to the argument that modern look attracts greater number of tourists, $80(40 \%)$ of respondents agreed, of which $8(4 \%)$ out of the group of young couples, $61(30.5 \%)$ are in full agreement, of which $5(2.5 \%)$ out of the group of young couples, $55(27.5 \%)$, agree in part, out of the group of young couples partly agreed $6(3 \%)$. Likewise, the argument that the modernly decorated Wellness Orhidelia attracts mainly young couples, totally agree 77 (38.5\%) respondents, of which half of the $10(5 \%)$ of the respondents from the group of young couples, $58(29 \%)$ of all respondents with argument in favor of which $7(3.5 \%)$ in the category of young couples. Among other things, the $79(39.5 \%)$ of respondents responded that they prefer wellness facilities, a similar result was also shown in the company that performs the analysis for their own needs, where it is also shown that more than 52 respondents (26\%) decided to visit Terme Olimia because of the spa services. Based on the results we can confirm H2: "The modern appearance of the company and the rich spa offer, the brand Terme Olimia arouse greater interest with young couples ".

Terme Olimia located at the site where the city is full of historical sights (from the castle to the monastery, monuments) and rich tourist offer that the provides respondents different sensations. Interesting history surrounding area attracts tourists, $58(29 \%)$ of the respondents are in full agreement of this statement, $69(34.5 \%)$ are in favor, $51(25.5 \%)$, agree in part. $20(10 \%)$ of respondents held, given the diverse surrounding offer, that affected the most, $85(42.5 \%)$ are of the opinion that has much influence, $54(27 \%)$ believe that it has some impact. The surrounding offer factor was estimated by the average value of 4.05 . Similarly, the average value was also given to the history surrounding towns factor, which was evaluated with 3.97. $63(31.5 \%)$ of the respondents are of the opinion that this factor has a great influence on the brand positioning, $80(40 \%)$ of respondents believe that has a significant impact, and $45(22.5 \%)$ of respondents think that they have some impact. According to the information obtained we may confirm the hypothesis H3: "An interesting history and varied offer of the surrounding towns has contributed much to the brand positioning. "The educated, motivated and skilled employees are the key to the success of the company. This view is also confirmed in Terme Olimia, because employees are trained both through internal workshops by departments, as well as abroad, for those who need such skills in the workplace. Internal trainings, relying primarily on the training of new employees, which may also be given mentors. There is a problem of understaffing in this company, as it is quite usual in this type of companies, that is why the company sometimes employs people that are not top experts in their field, but they are trying to lead them on the right track through internal training to become top experts. For motivation and proper performance, the company choosen rewarding system. The most hardworking and conscientious receive higher pay. It is not true that the company is only trying to enable staff to be the best, that is in fact how guests see them, because they claim that employees are friendly, motivated and trained to perform their work evaluated with an average of $4: 49$, which was the highest score among the allegations, the standard deviation was also the lowet, 0.69 . With this statement 117 (58.5\%) of respondents fully agreed, 67 (33.5\%) were in favor, $13(6.5 \%)$ partly agreed (table 3$)$. Also, the factor that influences on brand positioning, friendly and skilled employees, has been rated with an average rating of 4:45. $109(54.5 \%)$ are of the opinion that the mentioned factor has the greatest impact, $73(36.5 \%)$ felt that it has much impact. Respondents assessed factors on a five-point scale, where 1 meant "minimal impact" and 5 "most affected".

\section{Table 3: The average value and standard deviation for the various factors}

\begin{tabular}{|l|l|l|l|}
\hline $\begin{array}{l}\text { What factors affect the visibility and good brand positioning } \\
\text { in the industry? }\end{array}$ & PV & SD & $\mathbf{n}$ \\
\hline A rich spa offer & 4.33 & 0.72 & 200 \\
\hline Affordable prices & 3.99 & 0.95 & 200 \\
\hline The diverse surrounding offer & 4.05 & 0.81 & 200 \\
\hline Landscaped walking and cycling routes & 4.07 & 0.83 & 199 \\
\hline Advertising & 3.80 & 0.89 & 200 \\
\hline The healing thermal water & 4.13 & 0.78 & 199 \\
\hline Kindness and competence of staff & 4.45 & 0.67 & 200 \\
\hline Modern architectural appearance of the resort & 4.10 & 0.81 & 198 \\
\hline An interesting history of surrounding area & 3.97 & 0.91 & 199 \\
\hline Peace and a clean environment & 4.54 & 0.63 & 200 \\
\hline
\end{tabular}

Note: PV - average value, SD - standard deviation, $\mathrm{n}$ - the number of respondents

Also, the answers of the essay questions were no different. $35(17.5 \%)$ of the respondents replied that they were most satisfied, where $36(18 \%)$ of respondents thought that the main reason for visiting Term Olimia is professional and friendly 
staff. From all the data, we can confirm hypothesis $\mathrm{H} 4$ : "The company gives a strong emphasis on education and work motivation of its employees.".

In the light of all that we see when we visit Terme Olimia, we can conclude that the company used a lot of knowledge and skills to create such a successful company. Research has shown that the company is using a lot of knowledge management tools in brand positioning by using mechanisms for knowledge discovering with socialization (brainstorming, joint implementation of projects and co-operation between the departments, the introduction of new employees), the mechanisms for knowledge discovery with a combination (participation in problem solving, joint decision-making, participation in creating documents), mechanisms for capturing knowledge with internalisation (learning by doing, workplace training, one on one meetings), mechanisms for capturing knowledge with externalization (development of models or prototypes of good practice), mechanisms for capturing knowledge socialization (participation in communities of knowledge, a meeting of experts and interested people help users use knowledge tools and knowledge management tools, implementation of tracking meetings at various successful or less successful activities, habituation of new employees on ways of working in the company, observing the behavior of participants in the enterprise, informal gathering over coffee, mentoring), mechanisms for knowledge exchange to disseminate knowledge (publication of various reports, publications, regulations, publications, paper publications, presentations of organizational strategies), mechanisms for using knowledge, enabling routines (organizational policies, work practices, standards). They also use external experts which advise them on the development and investments.

In conclusion, the article provides a few suggestions for improvement, with them Terme Olimia could have greater visibility and thus better brand positioning both at home and abroad. If a company in fact wishes to determine its visibility and positioning, in addition to her other activities, we recommend that the company carries out extensive research both in the domestic as well as foreign market in order to find out whether they are actually the best among the Danube, the Alps and the Adriatic Sea. Our study did show a good review of the visibility and brand positioning, but there should also be something done in foreign markets, where was visibility and good positioning assessed slightly lower. In the light of everything that the company may offer, from modern appearance, to an exceptional spa offer and historically interesting and rich surroundings offer, all they can do is additional quality advertising (using Internet, Twitter and other websites, occasional special offers, ...). Given that the vast majority of respondents are impressed by their range of spa services, a company must invest knowledge and skills in this direction, and follow must follow the trends in the field of spa and pampering of consumers. It is important that the company continues to invest in knowledge and skills of employees, as they did by now and to try and motivate employees additionaly in some new way, such as public praise employee »of the month « title and similar. Although our research has shown that employees are motivated, friendly and trained for their work, undertaking education should not be abandoned, they should strive for more education and training. We suggest to the marketing sector of the company to use more knowledge management mechanisms, with existing knowledge tools they are already using, in order to enable routing.

\section{CONCLUSIONS}

Based on the results of the research we propose possible solutions to the enterprise for improvements in brand positioning and building the knowledge base of employees. Our results confirm the good brand positioning, which the respondents confirmed, slightly lower estimate of the assigned point-brand was abroad, which may be the reason that domestic consumers are not familiar with the situation abroad or brand is not positioned well. That the company will work out the positioning abroad, the employees knowledge is necessary, which are key factors of current state of the company its visibility and positioning. It is necessary, for the employees to use knowledge management systems to cover, discover, share and use knowledge. The friendly and knowledgeable staff is perceived as having a strong influence on brand positioning. The company is aware of the importance of knowledge management and its importance for the brand positioning. They use a large number of knowledge management mechanisms, thus helping the company to lead the way to its vision to set goals and along the way take into account the entire company's mission.

\section{REFERENCES}

[1] Barkovič, M. (2014). Pomen managementa znanja pri pozicioniranju blagovne znamke. (magistrska naloga). Celje; MFDPŠ

[2] Brezovec, A., in Nemec Rudež, H. (2009). Marketing v turizmu: Izhodišča za ustvarjalno razmišljanje in upravljanje. Portorož: Fakulteta za turistične študije - Turistica.

[3] Cencič, M. (2009). Kako poteka pedagoško raziskovanje: primer kvantitativne empirične neeksperimentalne raziskave. Ljubljana: Zavod RS za šolstvo.

[4] Dermol, V. (2011). Uvod v sisteme managementa znanja: dodatno študijsko gradivo 2010-2011. Celje: Mednarodna fakulteta za družbene in poslovne študije.

[5] Flere, S. (2000). Sociološka metodologija: Temelji družboslovnega raziskovanja. Maribor: Pedagoška fakulteta.

[6] Gomezelj Omerzel, D. (2008). Znanje zaposlenih ter poslovna uspešnost malih in srednje velikih podjetij. Koper: Fakulteta za management.

[7] Gomezelj Omerzel D., Biloslavo, R., in Trnavčevič, A. (2010). Management znanja v visokošolskih zavodih. Koper: Fakulteta za management. Pridobljeno s: http://www.fm-kp.si/zalozba/ISBN/978-961-266-076-5.pdf

[8] Kodrin, L. (2011). Trženje v turizmu. Celje: Fakulteta za komercialne in poslovne vede. 
[9] Konečnik, M. (2006). Izzivi proučevanja kompleksne narave blagovne znamke s pomočjo uravnoteženega pogleda nanjo. Organizacija, 39 (4), str. 265-272.

[10] Konečnik Ruzzier, M. (2011). Temelji trženja: Pristop k tržnemu načinu razmišljanja v 21. Stoletju. Ljubljana: Meritum.

[11] Kotler, P. (2004). Management trženja. Ljubljana: GV Založba.

[12] Kozjan, M., in Gomezelj Omerzel, D. (2012). Znanje v podjetju kot kritični dejavnik vrednosti blagovne znamke. Koper: Fakulteta za management. Pridobljeno s: http://www.fm-kp.si/zalozba/ISBN/978-961-266-127-4.pdf

[13] Mesec, B. (1998). Uvod v kvalitativno raziskovanje v socialnem delu. Ljubljana: Visoka šola za socialno delo.

[14] Možina, S. (2006). Vloga menedžmenta znanja v organizaciji. V S. Možina, in J. Kovač (ur.), Management znanja: znanje kot temelj razvoja: na poti k učečemu se podjetju (str. 129-151). Maribor: Založba Pivec.

[15] Pučko, D. (1998). Poslovodenje znanja in vpliv na strateško poslovodenje ter analizo. Organizacija, 31 (10), $557-565$.

[16] Richards, I., Foster, D., in Morgan, R. (1998). Brand Knowledge management: Growing Brand Equity, Journal of Knowledge Management, 2 (1), 47-54.

[17] Rode, N. (b. I.). Merjenje: merski instrumenti. Ljubljana: Fakulteta za socialno delo. Pridobljeno s: file:///C:/Users/Uporabnik/Downloads/2\%20Merskilnstrumenti\%20(1).pdf

[18] Terme Olimia. (b. I). Pridobljeno s: http://www.terme-olimia.com/sl

[19] Vidic, F. (2002). Marketinške strategije. Piran: Gea College, Visoka šola za podjetništvo.

[20] Vukasović, T. (2009). Raziskovalni model strateškega repozicioniranja blagovne znamke. Management 4 (3), 259279.

[21] Vukasović, T. (2012). Trženje: Od temeljev trženja do strateškega tržnega načrtovanja. Koper: Založba Univerze na Primorskem.

\section{AUTHOR' BIOGRAPHY WITH PHOTO}

Tina Vukasovič is an assistant professor in the International School for Social and Business Studies and on Doba Faculty, Slovenia. Her research interests include the areas of marketing research, consumer behaviour and brand management marketing. She is an author or coauthor of papers published in scientific journals and papers presented at scientific conferences.

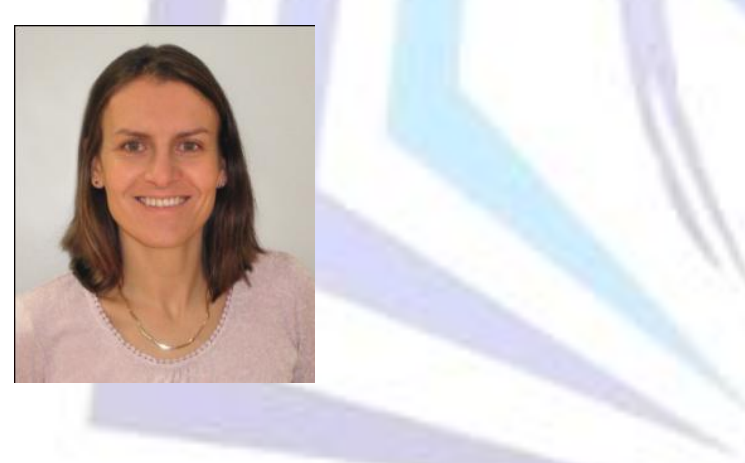

Martina Barkovič is currently employed in Ministry of the interior, Police station Brežice, Slovenia. Her research interests include the areas of marketing research, consumer behaviour and brand management marketing. She is a coauthor of this paper.

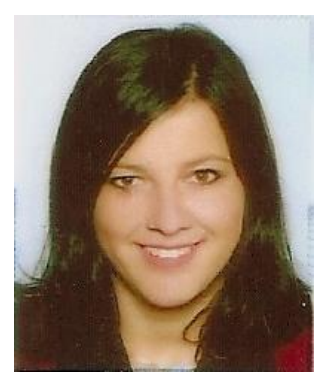

